\title{
Knowledge of Sickle Cell Disease in a Rural Community of Delta State, South-South Nigeria
}

\author{
Dr Nwagu, Marcellinus Uchechukwu ${ }^{1}$, Dr Ntaji M.I ${ }^{2}$, Dr Borke M.E ${ }^{3}$ \\ ${ }^{I}$ Senior lecturer/Consultant Haematologist Department of Haematology and Blood Transfusion, Faculty of \\ Clinical Medicine, Delta State University, Abraka, Delta State, Nigeria \\ ${ }^{2}$ Department of Community Medicine, Senior Lecturer/Consultant Community Health Physician Faculty of \\ Clinical Medicine Delta State University, Abraka \\ ${ }^{3}$ Department of Haematology and Blood Transfusion, Senior Lecturer/Consultant Haematologist Faculty of \\ Clinical Medicine, Delta State University, Abraka, Delta State, Nigeria
}

\begin{abstract}
Background: Sickle cell disease is a chronic debilitating condition. Nigeria has the largest pool of the sickle cell gene in the world. Three to five million people are affected in Nigeria. Knowledge of the disease may help in reducing the national prevalence.

Objective: To determine the level of awareness of sickle cell disease in a typical rural community of Delta State. Method: Structured researcher-administered questionnaires were used to collect information from residents of Akoku-Uno community of Delta state.

Resuts: One hundred and seventy four (174) persons were surveyed. Ninety two (52.9\%) were males while 82(47.1\%) were females. About thirteen percent (13.4\%) of the respondents have tertiary education. They were mainly farmers (31\%) and Christians (77.6\%); 76.4\% have heard about sickle cell disease. Knowing about the disease from seeing a sufferer (38.3\%), from friends (22.6\%) and radio (18.8\%). Only 5.3\% have heard about the disease from the church. It is a disease of the blood (45.1\%) and is inherited (27.8\%). The patients complain of bone pains(39.8\%), 72.2\% respondents said the best treatment is given by medical doctors and $12 \%$ knew the patients can become lawyers, doctors, engineers.

Conclusion: There is a high level of awareness of sickle cell disease among rural dwellers of Delta state. It is a disease of public health importance. Lack of tertiary education does not adversely affect awareness. The churches play a little role in the awareness of sickle cell disease. More \& continuous awareness campaigns should be launched in the churches and worship centres.
\end{abstract}

Keywords: Sickle Cell Disease In A Rural Community

\section{Introduction}

Sickle cell Anaemia (SCA) is a severe haemolytic disorder caused by the homozygous occurrence of the abnormal $\mathrm{S}$ haemoglobin (HbSS). The disorder results from a point mutation of adenine to thymine leading to replacement of glutamic acid by valine at the $6^{\text {th }}$ position of the beta-globin chain of human adult haemoglobin $(\mathrm{HbA}){ }^{1}$ The first reported case of sickle cell disease, historically, was in 1910. That was a Grenadan dental student who presented with very serious attacks of fever and cough, in addition to history of leg ulcers, yellowness of the submucous membranes (jaundice)and exercise intolerance. ${ }^{2}$ The incidence of sickle cell disease captures the worldwide distribution of Malaria parasite (Plasmodium falciparum) because it has been believed that in early childhood the sickle cell trait confers some protection against malaria. However, because of migration of peoples from the tropics to the developed industrialized western countries, sickle cell disease has become common in places where malaria is not endemic. ${ }^{3}$ The Centre for Disease Control (CDC) and prevention in the United States of America estimates that sickle cell anemia is present in 500 African American live births. As at 2002, in the United States of America more than 1million dollars is spent each year for hospitalization of patients with sickle cell disease ${ }^{4}$. In Nigeria, 45,000 to 90,000 babies are delivered yearly with Sickle Cell Disease ${ }^{5}$ and the total incidence of sickle cell anaemia is about $2 \%$. Nigeria with an estimated population of about 200 million people, this seemingly small incidence creates serious burden on the healthcare delivery system as 3-5million Nigerians are affected by the disease. ${ }^{6,7}$ Therefore, Nigeria, has the largest sickle cell gene pool in the world. Studies have revealed that there is deficient knowledge of Sickle Cell Disease among graduates and students in tertiary institutions ${ }^{8,9}$. There is also poor community knowledge about sickle cell disease among African-American women where ninety-one percent of the participants believed that Sickle Cell Disease was a hereditary blood disorder but only $9.3 \%$ understand the hereditary pattern of sickle cell isease. ${ }^{10}$ Delta State University Teaching Hospital (DELSUTH), Oghara, is a relatively new tertiary health institution located in a rural community of Delta state and many cases of sickle cell disease are managed by the hospital and in most cases they present to the hospital very late with various complications of sickle 
cell disease such as sickle cell nephropathy or acute chest syndrome. No study has been done on the level of awareness of sickle cell disease in rural areas of Delta state and this study therefore intends to ascertain the degree of knowledge of sickle cell anaemia in a typical rural community of the state and also to determine area(s) where awareness campaigns and programmes need to be improved and emphasized upon for maximum understanding of the disease in the rural populace. In addition, the data generated from this study will serve as reference values and also provide a good platform for public awareness campaign concerning sickle cell disease in our rural community.

\section{Subjects And Methods}

This work is a cross-sectional study which was carried out at Akoku-Uno Community in Ukwuani Local Government Area of Delta State. The permission of the community leader was obtained prior to the commencement of the study. The community is inhabited by a population of about 17,082 people and the people are mostly farmers and speak the Ukwuani language which is synonymous with Ika, the language of the Delta Ibos. An approval for the study was obtained from Health Research Ethics Committee (HREC) of Delta State University Teaching Hospital, Oghara. Informed consent was obtained from voluntary participants of the study. The study population consisted of residents aged 14years and above who are inhabitants of Akoku-uno community and able to answer questions as contained in the questionnaire. Visitors to the community were excluded from the study. Semi structured questionnaire was used to collect information from respondents after obtaining verbal consent from them. Information on the sociodemographic characteristics of the respondents and their awareness of sickle cell disease were obtained. In addition, other information obtained include sources of respondents' awareness, their understanding of definition of sickle cell disease.

Data analysis: IBM SPSS version 22.0 software was used for data analysis. Frequency distribution tables were used for presentations of selected variables.

\section{Results}

A total of one hundred and seventy four (174) persons were interviewed Table 1 shows the sociodemographic characteristics of respondents. The overall mean age was $30.48 \pm 13.31$ years. The age range was 14-82 years, respectively. Ninety two respondents(92/174;52.9\%) were males while $82 / 174(47.1 \%)$ were females, giving a female to male ratio of 1 to 1.12 . The level of literacy was very low as only 24/174(13.4\%) of the respondents had tertiary education. Occupation of the respondents revealed that majority were farmers $54 / 174(31 \%)$ and students 49/174(28.2\%). In terms of marital status, majority of respondents $143 / 174(82 \%)$ were married. Religious affiliation showed that majority were Christians. Figure 1 shows the proportion of respondents who have heard about sickle cell disease. One hundred and thirty three $\{133 / 174 ;(76.4 \%)\}$ respondents agreed that they have heard about sickle cell disease. Out of these 133 respondents, 77/133( 57.9\% ) were males and 56/133(42.1\% ) were females. In other words, of the male population, $83.7 \%$ have heard about the disease while $68.3 \%$ of females have also heard about the sickle cell disease.(see table 2)Table 3 revealed the source of knowledge of sickle cell disease. Those who heard about the disease from the experience of seeing a sufferer are of the majority 51/133 (38.3\%). This is followed by hearing from friends 30/133(22.6\%) and radio $25 / 133(18.8 \%)$, respectively. About $5 \%$ of respondents $(7 / 133)$ heard about the disease from the church.Table 4 shows the respondents definition of sickle cell disease. Forty-five percent $(45 \%)$ of respondents knew that SCD was a blood disorder while 37/133 (27.8\% ) knew that it was an inherited condition.

Table 5 shows the respondents' knowledge about the complaints of patients with sickle cell disease. Fifty-three respondents, $\{53 / 133(39.8 \%)\}$ know the patients complain of bone pains while 36/133(27.1\%) know the patients present with shortage of blood and 14/133(10.5\%) knew the patients complain of yellowness of the eyes. Only $4.5 \%$ of respondents know the sickle cell disease patients complain of hand and leg swellings. Table 6 revealed the knowledge of the respondents on the best person who treats sickle cell disease patients. Ninetysix, 96/133(72.2\%) respondents knew that the best treatment is given by medical doctors, 19/133 (14.3\%) said the native doctors provide the best treatment to the patients. Nine of the respondents, 9/133( 6.8\%) and 4/133 $(3.0 \%)$ said the nurse and the pastor provide the best treatments, respectively.Table 7 shows the respondents' knowledge about the prognosis of sickle cell disease. Fifty-five, 55/133(41.4\%) said the patients live normal lives while 49/133 (36.8\%) said the sickle cell disease patients die prematurely. Twelve percent of respondents $\{16 / 133 ;(12 \%)\}$ knew the patients can attain big professions like laywers, doctors, engineers while 13/133 $(9.8 \%)$ said the sickle cell disease patients are not normal human beings.

\section{Discussion}

This study showed a female to male ratio of 1 to 1.12 similar to a study in eastern Nigeria on awareness of sickle cell anaemia among university undergraduates ${ }^{7}$.There is low level of literacy from this study, very few had tertiary education. Majority of the respondents had secondary education. This is also reflected in the occupation of the respondents which is mainly farming. The pattern here is after secondary education, most of 
them take to farming. The people see farming as a major occupation and a good source of income. Secondly, this study has demonstrated a level of awareness which was good meaning their lack of tertiary education does not negatively impact on awareness Majority of the respondents have heard about the disease and are aware of sickle cell anaemia. Their source of awareness is mainly from seeing the sufferers and also information from friends. As majority of the respondents $(77.6 \%)$ were Christians, one would have expected the source of awareness to have come mainly from the churches. This implies that more awareness campaigns should be launched in churches. In this part of the world people listen and obey their pastors and therefore in collaboration of church pastors this will improve more on the awareness.

In this study, only $5 \%$ of respondents got the information about SCD from churches. This is highly unexpected, considering the level of religiosity of Nigerians. There may be the need for the appropriate agent of government concerned with SCD to partner with the churches in order to improve awareness.

Despite low level of tertiary education among respondents, they were able to know the definition of sickle cell anaemia. Again, more than seventy percent of respondents are aware that medical doctors offer the best treatment to patients suffering from sickle cell disease while about forty percent $(39.8 \%)$ knew that bone pains is the common complaints by sickle cell disease patients. All these lay credence to the fact that there is high level of awareness despite poor tertiary education. However, despite the high level of awareness, very few of the respondents know that people with sickle cell disease can attain great height in seemingly difficult and challenging professions like medicine, law and engineering. A lot of emphasis should be laid in this regard during further awareness campaigns in the rural community

\section{Conclusion}

There is high level of awareness of sickle cell disease in rural population despite low level of tertiary education an indication that lack of tertiary education does not adversely affect awareness of sickle cell disease. There is need by government agencies to partner with churches to improve awareness especially in the area of prognosis and career pursuit of patients with sickle cell disease. Awarenes from seeing the sufferers of sickle cell disease indicates that it is a disease of public health importance.

\section{References}

[1]. Halim NKD, Famodu AA. Textbook of Clinical Haematology, Benin City, Ambik press, 1997, pg 25.

[2]. Herrick JB. Perculiar elongated and sickle shaped red corpuscles in a case of severe anemia. Arch intern Med 1910; 6: 517-600

[3]. Natarajan K, Townes TM, Kutlar A. Disorders of haemoglobin structure: sickle cell anaemia and related abnormalities. In: Kaushansky K, Lichtman MA, Beutler E, Kipps TJ, Seligsohn U, Prchal JT (eds), Williams Hematology, $8^{\text {th }}$ edn, New York, McGraw Hill, 2010, 710-711.

[4]. Okumura MJ, Campbell AD, Nasr SZ, Davis MM. In patient health care use among adult survivors of chronic childhood illnesses in the Unites States. Arch Pediatr Adolesc Med 2006;160: 1054-1058

[5]. Taylor LE, Stotts NA, Hunphreys J, Treadwell MJ, Miaskowski C. J pain symptom manage 2010; 40(3): 416-435

[6]. Akinyanju O. Issues in the management and control of sickle cell disorders. Arch Ibadan Medicine 2001; 2(2): 37-41.

[7]. Olatunji PO. Between 3 and 5 million Nigerians have sickle cell anaemia. Afr sickle cell. 2011;3:14 and 29.

[8]. Adewuyi JO. Knowledge of and attitudes to ssickle cell disease and sickle carrier screening among new graduates of Nigerian tertiary educational institutions. Niger Postgrad Med J 2000; 7(3):120-123

[9]. Alao OO, Araoye M, Ojabo C. Knowledge of sickle cell disease and haemoglobin electrophoresis. Niger J Med 2009; 18(3):326329

[10]. Inadequate community knowledge about sickle cell disease among African-American women. J Natl Med Assoc 2005; 97(1): 62-67

[11]. Agbanusi O, Amaechi C, Onyejizu C et al. Awareness of sickle cell anemia and its heterozygous state among undergraduate students of the university of Nigeria, Enugu campus, Enugu. Medikka. www.medikkajournal.com (assessed May 2016)

Figures and Tables

FIG. 1 Shows the respondents who have heard and those who have not heard of SCD

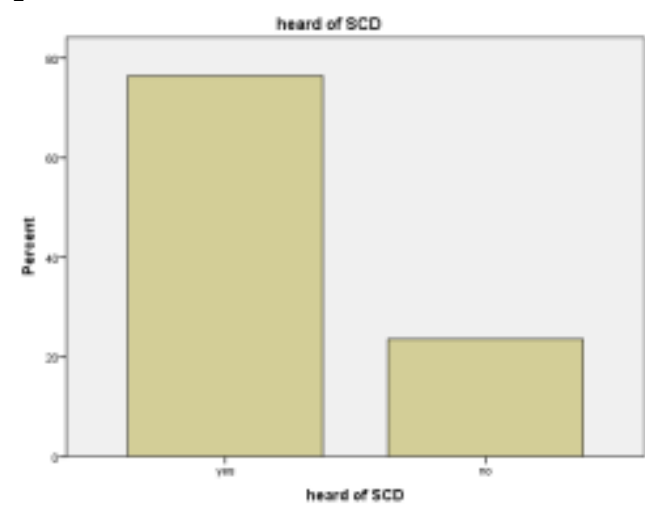




\section{TABLES}

\section{TABLE 1: Sociodemographic Characteristics Of Respondents}

\section{Characteristics}

Sex

Male

Female

Educational status

Primary

Secondary

Tertiary

NONE

\section{Occupation}

Farming

Trading

Teaching

Student

Others

Marital status

Single

Married

Divorced

Widow/widower

Not indicated

\section{Religion}

Christians

Muslims

Jehova witness

ATR

Not indicated

\section{Frequency (\%)}

92(52.9)

$82(47.1)$

174(100)

$42(24.1)$

93(53.4)

24(13.4)

15(8.6)

174(100)

54(31.0)

29(16.7)

11(6.3)

$31(17.8)$

174 (100)

24(14.0)

143(82.0)

3(1.6)

2(1.2)

174(100)

$$
\begin{array}{r}
135(77.6) \\
3(1.7) \\
14(8.0) \\
18(10.3) \\
4(2.3) \\
\mathbf{1 7 4 ( 1 0 0 )}
\end{array}
$$

Table2: Heard Of Sickle Cell Disease Among The Gender

\begin{tabular}{|l|l|l|l|}
\hline Gender & & Frequency & Percent \\
\hline \multirow{3}{*}{ Female } & Yes & 56 & 68.3 \\
\cline { 3 - 5 } & No & 26 & 31.7 \\
\cline { 3 - 5 } & Total & 82 & 100.0 \\
\hline \multirow{3}{*}{ Male } & Yes & 77 & 83.7 \\
\cline { 3 - 5 } & No & 15 & 16.3 \\
\cline { 3 - 4 } & Total & 92 & 100.0 \\
\hline
\end{tabular}

Table 3: Source Of Knowledge Of Sickle Cell Disease

\begin{tabular}{|l|l|l|l|}
\hline \multicolumn{2}{|l|}{ Source } & Frequency & \\
\hline \multirow{4}{*}{} & Radio & 25 & 18.8 \\
\cline { 2 - 4 } & Church & 7 & 5.3 \\
\cline { 2 - 4 } & Friend & 30 & 22.6 \\
\cline { 2 - 4 } & Seen a sufferer & 51 & 38.3 \\
\cline { 2 - 4 } & TV/NP & 20 & 15.0 \\
\cline { 2 - 4 } & Total & 133 & 100.0 \\
\hline
\end{tabular}

TV/NP = Television/Newspaper 
TABLE 4: Definition Of Sickle Cell Disease

\begin{tabular}{|l|l|l|l|}
\hline \multicolumn{2}{|c|}{} \\
\hline \multicolumn{2}{|c|}{ Definition } & Frequency & Percent \\
\cline { 2 - 4 } & Disease of blood & 60 & 45.1 \\
\cline { 2 - 4 } & Ogbanje & 15 & 11.3 \\
\cline { 2 - 4 } & Curse from gods & 12 & 9.0 \\
\cline { 2 - 4 } & Inherited & 37 & 27.8 \\
\cline { 2 - 4 } & others & 9 & 6.8 \\
\cline { 2 - 4 } & Total & 133 & 100.0 \\
\hline
\end{tabular}

TABLE 5: Usual Complaints Of Sickle Cell Disease Patients

\begin{tabular}{|l|l|l|l|}
\hline \multicolumn{2}{|c|}{ Complaints } & Frequency & Percent \\
\hline \multirow{4}{*}{} & Bone pains & 53 & 39.8 \\
\cline { 2 - 4 } & Yellownes of eyes & 14 & 10.5 \\
\cline { 2 - 4 } & Lack of blood & 36 & 27.1 \\
\cline { 2 - 4 } & Hand/leg swelling & 6 & 4.5 \\
\cline { 2 - 4 } & I don't know & 17 & 12.8 \\
\cline { 2 - 4 } & Others & 7 & 5.3 \\
\cline { 2 - 4 } & Total & 133 & 100.0 \\
\hline
\end{tabular}

TABLE 6: Sickle Cell Disease Is Best Treated By

\begin{tabular}{|l|l|l|l|}
\hline \multicolumn{2}{|c|}{ Treated by } & Frequency & Percent \\
\hline \multirow{4}{*}{} & Medical doctor. & 96 & 72.2 \\
\cline { 2 - 4 } & Nurse & 9 & 6.8 \\
\cline { 2 - 4 } & Native doctor, & 19 & 14.3 \\
\cline { 2 - 4 } & Pastor & 4 & 3.0 \\
\cline { 2 - 4 } & Others & 5 & 3.8 \\
\cline { 2 - 4 } & Total & 133 & 100.0 \\
\hline
\end{tabular}

TABLE 7: Prognosis Of Sickle Cell Disease

\begin{tabular}{|l|l|l|l|}
\hline \multicolumn{2}{|l|}{ Prognosis } & Frequency & Percent \\
\hline \multirow{3}{*}{} & Live normal life & 55 & 41.4 \\
\cline { 2 - 4 } & Premature death & 49 & 36.8 \\
\cline { 2 - 4 } & Not a normal person & 13 & 9.8 \\
\cline { 2 - 4 } & Can be a Dr/lawyer & 16 & 12.0 \\
\cline { 2 - 4 } & Total & 133 & 100.0 \\
\hline
\end{tabular}

